\title{
Personality and Ideology
}




\title{
Critical Texts in Social Work and the Welfare State
}

\author{
General Editor: Peter Leonard \\ Pete Alcock and Phil Harris \\ WELFARE LAW AND ORDER \\ Ragnhild Banton, Paul Clifford, Stephen Frosh, \\ Julian Lousada, Joanna Rosenthall \\ THE POLITICS OF MENTAL HEALTH
}

Steve Bolger, Paul Corrigan, Jan Docking and Nick Frost TOWARDS SOCIALIST WELFARE WORK:

WORKING IN THE STATE

Paul Corrigan and Peter Leonard SOCIAL WORK PRACTICE UNDER CAPITALISM:

A MARXIST APPROACH

Norman Ginsburg CLASS, CAPITAL AND SOCIAL POLICY

Ian Gough

THE POLITICAL ECONOMY OF THE WELFARE STATE

Chris Jones

STATE SOCIAL WORK AND THE WORKING CLASS

Peter Leonard

PERSONALITY AND IDEOLOGY: TOWARDS A MATERIALISTIC UNDERSTANDING OF THE INDIVIDUAL

Chris Phillipson

CAPITALISM AND THE GONSTRUCTION OF OLD AGE

\author{
Forthcoming \\ Lena Dominelli and Eileen McLeod \\ FEMINISM AND WELFARE: \\ SOCIAL ACTION AND SOCIAL WORK \\ Paul Henderson and Pat Taylor \\ BEYOND VOLUNTARISM: VOLUNTARY WORK AND THE \\ CRISIS OF THE WELFARE STATE
}




\title{
Personality and Ideology Towards a Materialist Understanding of the Individual
}

\author{
Peter Leonard
}

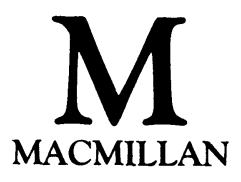


All rights reserved. No reproduction, copy or transmission of this publication may be made without written permission.

No paragraph of this publication may be reproduced, copied or transmitted save with written permission or in accordance with the provisions of the Copyright Act 1956 (as amended).

Any person who does any unauthorised act in relation to this publication may be liable to criminal prosecution and civil claims for damages.

First published 1984

Reprinted 1985

Published by

MACMILLAN EDUCATION LTD

Houndmills, Basingstoke, Hampshire RG21 2XS

and London

Companies and representatives

throughout the world

ISBN 978-0-333-34726-3

ISBN 978-1-349-17439-3 (eBook)

DOI 10.1007/978-1-349-17439-3 
This book is for Lynne with my love 


\section{Contents}

Preface $\quad \mathrm{x}$

1 Introduction: The Need for a Materialist Understanding of the Individual

A question of practical necessity

The gap in Marxism

The purpose and plan of the book

PART I MATERIALISM AND PSYCHOLOGICAL THEORY

2 The Limitations of Psychology 11

Major trends in psychology 12

$\begin{array}{ll}\text { Enter historical materialism } & 19\end{array}$

Intellectual production and material structure $\quad 20$

Materialism and the individual 23

Psychology and 'human nature' $\quad 29$

Psychoanalysis and ideology 32

3 Materialism, Instinct and Intention 39

Freudianism as a response to Marxism's 'failure' $\quad 40$

Sexual repression and class struggle $\quad 42$

Women's psychology and patriarchal relations $\quad 47$

Production, consumption and class relations $\quad 56$

Social being and biological being $\quad 64$

Human intention and the self $\quad 70$

4 Personality Theory from within Historical Materialism

Humanism and alienation theory $\quad 77$

Personality development and social labour $\quad 83$ 
Acts, capacities and needs $\quad 87$

The structure of personality and use-time $\quad 90$

A general topology of personalities $\quad 92$

Psychological superstructures $\quad 96$

Production, ideology and gender 99

5 Key Concepts in a Materialist Analysis 102

Problems of theory 102

Omissions 105

$\begin{array}{ll}\text { Summary of key concepts } & 109\end{array}$

PART II PERSONALITY DEVELOPMENT WITHIN CAPITALISM

6 Entering the Social Order 121

The triumph of the bourgeois family form $\quad 122$

$\begin{array}{ll}\text { The penetration of ideology } & 129\end{array}$

The dialectic relationship between parent and child 135

Material determinants and use-time 138

Instinctual repression and redirection $\quad 141$

Problems and deprivations $\quad 145$

$\begin{array}{ll}\text { State intervention in childhood } & 147\end{array}$

$\begin{array}{ll}\text { The older child and the young adult } & 150\end{array}$

7 Working in the Social Order 153

Performing socially necessary labour $\quad 154$

The experience of wage labour $\quad 160$

Parental roles and familial ideology 165

Contradictions in family and sexual relations $\quad 170$

The state and the parent 174

Contradictory consciousness and adult personality $\quad 178$

8 Marginality in the Social Order 180

Poverty and the absence of wage labour 182

The ideological context of marginality 187

The self, identification and repression 191

9 Personality Development and Collective Action 202

Pessimism and the incorporation of dominant ideology 203

Revolutionary praxis 206

Consciousness-raising 208 
Varieties of political practice

Psychological benefits of collective action

Conclusion

$\begin{array}{lr}\text { References } & 218\end{array}$

Index 


\section{Preface}

The origins of this book could be traced to a time, nearly twenty-five years ago, when, like most social workers, I lived in a professional culture dominated by social reformism and Freudian theory. It was after an education in sociology and social administration that I gained my introduction to psychoanalytic theory and the practice of psychiatric casework. Some time later I contributed to the teaching of subjects called 'Human Growth and Development' and 'Social Influences on Behaviour', subjects which were based on a psychoanalytic conception of the human life cycle injected with a mild dose of structural-functional sociology.

All of this took place before I became disillusioned with the social reformism which was the explicit political culture in which I had worked. As I gradually became committed to Marxism as a politics, a theory and a method of historical analysis, I re-evaluated all my previous intellectual allegiances. Apart from rejecting much of the mainstream sociology and social administration of which I had previously been part, I felt impelled to turn aside from the psychoanalytic-based insights and skills which I had developed over many years of professional practice. I wished to avoid the reductionism and liberal pessimism with which such insights and skills were often associated.

In more recent years, partly under the strong impact of feminism, I have been forced, like many others, to return to Freud once more. Despite its obvious limitations as a view of human beings and the reactionary purposes to which it has often been put, perhaps it still has, I thought, some possibilities when it is interrogated from the perspectives of Marxism and feminism. At the same time, I have been introduced to the 
beginnings of a theory of the individual in Marx's work, and to the potentials which lie in symbolic interactionism, first revealed to me as a possibly progressive approach at the National Deviancy Conferences of the early 1970s. It is from immersion in this heady mixture of frequently conflicting approaches to the individual that this book breaks to the surface.

Apart from the more obvious theoretical and technical problems posed by writing this book comes a specifically political one. A book which attempts to give some account of the material existence and psychological experiences of others, even at a very general level and from what attempts to be a socialist perspective, runs the danger of appearing both to psychologise their situations and appropriate their experiences for purposes outside their particular interests. Feminists have rightly resisted the attempts of men to colonise their work, from a similar standpoint to that of people with disabilities who are beginning to resist the definitions of their situation produced by able-bodied 'experts'. I hope that in this book I have been able to avoid these particular dangers: the reader must judge.

As this book represents, for me, a settling of accounts with my professional and academic past, attempting to acknowledge all the influences on my writing would be a major task. Instead, I shall mention just one name from over twenty years ago Donald Winnicott, paediatrician and psychoanalyst, who taught me how a theory could be integrated into a practice that was supremely sensitive, imaginative and reflective. More recently influential was the impact on me of the students who participated in my postgraduate seminars on Marxism and psychoanalysis and on personality development and social structure at Warwick University. My colleagues in the Department of Applied Social Studies have been immensely encouraging in their support, Lena Dominelli, Eileen McLeod and Janet Read in particular contributing helpful criticisms of drafts of the book. A former fellow-student of many years ago, like me exposed then to a powerful psychoanalytic influence, Elizabeth Wilson, also provided me with valuable comments. My special thanks must go to Janet Sayer of the University of Kent and Mike Seltzer of Norges Kommunal-Og Sosialhøgskole, Oslo, for their unstinting and detailed criti- 
xii PREFACE

cisms and comments on the book, a combination of scholarship and commitment which I found inspiring. Without Lydia Thorpe, who so faultlessly typed from the handwritten manuscript, my task would have been much harder. Finally, I must express my appreciation to my wife, Lynne, for providing so much encouragement and support, especially during the final weeks of rewriting when we were not sure which would be produced first, the book or our second child.

University of Warwick

September 1983

Peter Leonard 